\title{
Sisters in Solidarity: Resistance and Agency through Urban Community Food Gardens in Pietermaritzburg
}

\section{Linda Naicker ${ }^{1}$}

\section{${ }^{1}$ SHORT BIO}

Linda Naicker is a Researcher at the Research Institute for Theology and Religion, UNISA and a Doctoral Candidate at University of Western Cape, South Africa. Her research interests and publications focus on the intersections of religion, race, class and gender. This work is based on research supported by the National Research Foundation of South Africa under auspices of the Desmond Tutu Chair in Religion and Social Justice (Grant number: 118854).

\section{INSTITUTIONAL AFFILIATION}

Research Institute for Theology and Religion, UNISA; Doctoral Candidate at University of Western Cape, South Africa;

Naicklw@unisa.ac.za or

l.w.naicker@gmail.com

\section{ORCID}

https://orcid.org/0000-0003-1347-9893.

\begin{abstract}
In this article I explore the solidarity, resistance and agency of a group of women involved in an urban community food garden project in collaboration with the Pietermaritzburg Agency for Community Social Action (PACSA). I explore this initiative through the lenses of African Women's Theology (AWT) and Oikos Theology and suggest that urban community food gardens represent a cooperation with nature and a resistance to social structures and systems that perpetuate marginalization, inequality, and subjugation of women. AWT provides a means to theorize and theologize women's suffering and agency, and Oikos Theology recognizes the connection between economy and ecology. I tease out how ecological and indigenous wisdom applied in urban community food gardens results in a mutually sustaining relationship between local communities and the earth. I also show how the development of an ecological consciousness not only serves to mitigate food insecurity but empowers women to resist systems and structures of oppression and to embrace affirming and life-giving traditions.
\end{abstract}

\section{KEYWORDS}

African Women's Theology, community urban food gardens, ecological wisdom, food insecurity, indigenous wisdom, Oikos Theology

\section{Introduction}

In this article I focus on women who participate in urban food gardening in the city of Pietermaritzburg and examine their agency and ecological astuteness. Through the lens of AWT, I demonstrate how urban community food gardens have become not just a measure to mitigate food insecurity but a space where women could unite in a common struggle against a myriad of social woes brought on by structural inequalities. The socioeconomic struggle for people living in under-resourced areas is systemic, 
pervasive and destabilizing. ${ }^{1}$ Amidst it all, women navigate, struggle and demonstrate agency through resistance and solidarity. Through the lens of Oikos Theology, I suggest that urban community food gardeners in Pietermaritzburg resist economic injustice and oppression by reclaiming access to the land (albeit temporarily) which was taken under apartheid. By employing ecological and indigenous wisdom in tending the soil and taking care of nature, a mutually sustaining relationship between the food gardeners and the earth is achieved and food insecurity is alleviated.

\section{A propitious encounter}

When I embarked on my doctoral studies in 2017, I first encountered a group of women working on urban food gardens in the city of Pietermaritzburg. My affiliation with the Pietermaritzburg Agency for Community Social Action (PACSA), began in 2007, when, as a student worker for the Ujamaa Centre, University of KwaZulu-Natal, I assisted in conducting a series of contextual Bible studies on gender related issues at PACSA. My awareness of the social justice work undertaken by PACSA is what prompted me to approach them to request that they act as gatekeeper ${ }^{2}$ for my research. The response was positive and led to my working with the group of women who partner with PACSA vis-à-vis urban food gardens.

Established as a Faith Based Organization (FBO) in 1979, PACSA is located in the city of Pietermaritzburg. Working within a social justice paradigm, the initial task of PACSA was the conscientization of white Christians in South Africa about the evils of apartheid and the impact of its oppression on the majority of South Africa's population. ${ }^{3}$ Over time, and with the eradication of

1 Yousif Ismael Abdulla, "Causes of food Insecurity in Southern Africa: An Assessment," (Masters diss., University of Stellenbosch, 2007), 20-21.; Jonathan Crush and Mary Caesar, "City without Cchoice: Urban Food Insecurity in Msunduzi, South Africa," Urban Forum 25 (2014):165-175.

2 A gatekeeper is an individual or organization that acts as an intermediary between a researcher and potential research participants.

3 Charles Manda, "Doing Theology at the Margins: PACSA's Accompaniment of Communities in the KwaZulu-Natal Midlands, 1979-2012," Studia Historiae Ecclesiasticae 40, no 2 (2014): 263. 
apartheid, PACSA's mandate changed to serving marginalized communities still grappling with the legacies of apartheid's oppression. ${ }^{4}$ Guided by what it calls a 'theology of accompaniment,' PACSA privileges a preferential option for the poor, ${ }^{5}$ and works towards community development and transformation. Through its core strategy of process facilitation, PACSA partners with local communities in efforts to build citizenship and restore human dignity. ${ }^{6}$

As a researcher interested in the lived realities of women on the margins of society-their interests, concerns, struggles, challenges and triumphs-I was keen to observe the inner workings of the group because of their commitment to dealing with issues of food insecurity in their communities, and because they provided links to community knowledge that I would otherwise not have access to. PACSA invited me to journey with the group of women (with their permission) for a short while as they worked on urban food gardens in collaboration with PACSA. This group of urban food gardeners would subsequently become research participants in my doctoral research.

The gardeners are deeply embedded in their local communities, and have a profound interest in the well-being and development of these communities, particularly that of women. Aside from their work on urban food gardens in the city, the gardeners undertake other income generating measures to sustain themselves and their families. Their income generating activities also serve to spearhead community-centered support groups that address particular community needs and challenges. The group's creative endeavours represent a form of resistance to structural inequalities that result in food insecurity and other social problems.

4 See PACSA's work with the urban poor at: Julie Smith and Mervyn Abrahams, "PACSA Food Price Barometer," PACSA, Pietermaritzburg, November 2016, 2.

5 A preferential option for the poor is built on the premise that poverty and inhumanity is contrary to the will of God. See Gustavo Gutierrez, On Job, (Maryknoll: Orbis, 1987), 94.

6 Manda, "Doing Theology at the Margins," 263-280. 
Falling between the ages 28 and 60 , each of the ten community food gardeners belonged to a township or informal settlement in and around Pietermaritzburg. Deeply committed to their Christian faith, they represented various Christian denominations. Each of them also spearheaded community support groups within their communities to address social justice issues relevant to their communities. The women were a mixed group consisting of single, married and widowed women with families to support. A few were grandmothers responsible for the guardianship or care of their grandchildren.

\section{Food insecurity in Pietermaritzburg}

South Africa is viewed as a food secure nation. This means that it has the capacity to produce enough food and the means to import food in instances of deficit. Yet, research in the field of food security reveals high levels of food insecurity across the country. ${ }^{7}$ Even though there is an availability of food, many people do not have access to sufficient nutritious food due to poverty, unemployment, and other social factors. Due to the spatial and socioeconomic segregation of cities in South Africa, urban food insecurity is pervasive and affects predominantly the low-income urban poor. The prevailing inequitable social structures in South Africa-the vestiges of apartheid-further exacerbate the levels of disparity. The gap between the rich and the poor continues to grow, even under the post-apartheid dispensation. ${ }^{8}$

In Pietermaritzburg and the surrounding areas, research reveals that a large percentage of urban households are food insecure and rely upon social grants as their only source of income. ${ }^{9}$ With households ranging from around 7 to 10 members on average, it is impossible to provide sustenance for an

7 Jonathan Crush and Bruce Frayne, "The Invisible Crisis: Urban Food Security in Southern Africa," Urban Food Security Series No. 1. (Kingston and Cape Town: Queen's University and AFSUN, 2010), 5.

8 Jane Battersby, "A Call for a Food Systems Approach to Alleviating Food Insecurity" Input for Province (September 2015): 3.

9 Battersby, "A Call for a Food Systems Approach," 2. 
entire family with the meagre sum received through social grants of R300 per child and R1700 for pensioners. ${ }^{10}$ With high unemployment rates, rising food prices and escalating transportation and schooling costs, households must find other means of income generation and food supply. ${ }^{11}$

Research also reveals that women are most affected by food insecurity. ${ }^{12}$ Due to the evolving familial system, where the heads of households are often women, it is incumbent upon them to find pragmatic and agentive ways of putting food on the table. ${ }^{13}$ Research shows that, though women are the backbone of many under-resourced households, they are often more marginalized than their male counterparts. ${ }^{14}$ Due to the feminization of poverty, ${ }^{15}$ its severity is most pervasive among women and children and it is extremely arduous for women to lift themselves and their children out of such a state. Compounding the issue of poverty are the lack of access to important services such as health care and housing, as well as lack of proper plumbing and sanitation systems in homes. ${ }^{16}$ These put a strain on women as they struggle to acquire sufficient water to cook healthy meals and take care of their households. This also negatively impacts women's health and the health of their families. Consequently, many women in South Africa still find themselves totally crushed by the weight of socio-economic

10 Battersby, "A Call for a Food Systems Approach," 3.

11 Battersby, "A Call for a Food Systems Approach," 4.

12 Belinda Dodson, Asiyati Chiweza and Liam Riley, "Gender and Food Insecurity in Southern African Cities," AFSUN Food Security Series, no. 10 (2012), 3.

13 Battersby, "A Call for a Food Systems Approach," 4.

14 Dodson, Chiweza and Riley, "Gender and Food Insecurity," 3.

15 The term 'feminization of poverty' refers to the widening gender gap in poverty that is caused by inequality between genders in living standards, livelihood opportunities, deferential pay for similar work, and lack of a level playing field in education and employment, among other causes. It refers to the phenomenon of a disproportionate percentage of women and children found in the low-income category than men belonging to a similar socio-economic group. Southern African Studies 37, no.4 (2011):781-807; Crush and Frayne, "The Invisible Crisis," 54. 
deprivation. ${ }^{17}$ Food insecurity has proved to be one of the main areas of vulnerability for under-resourced women, living on the margins of society in the Msunduzi Municipality. ${ }^{18}$

\section{African Women's Theology (AWT)}

African Women's Theology is a form of liberation theology. ${ }^{19}$ Its theological and empirical approach is contextual and communal. The liberationist tenets of AWT include an ethic of resistance and transformation, creating a space for African women and men to deal with all forms of domination and oppression. ${ }^{20}$ It extends beyond merely seeking liberation for women, by seeking the liberation of all people - men, women and children in all of society. It is a protest against the subjugation of African women in church and society, leading women to rise up against the forces of oppression and injustice, be it socio-economic, political, religious or cultural. AWT is committed to women at the grassroots level, to women in the academy, and the church. ${ }^{21}$ As such, it speaks the language of the academy and the community, linguistically, culturally and socially. ${ }^{22}$ It engages themes of religion and theology, social justice, equity, inclusion and solidarity across race, class, gender and ethnic lines, aiming to be both prophetic and activist. ${ }^{23}$ AWT takes seriously the idea of human dignity for all and the notion that African women's oppression is intertwined with racism, socio-

17 Frank Chikane, "Reflections of South Africa's Oikos Journey: From Apartheid to Democracy," Diakonia Council of Churches, 2006. 1.

18 Crush and Frayne, "The Invisible Crisis." 5.

19 African Women's Theology focuses on oppressive religio-cultural, political and economic systems that disenfranchise African women.

20 Ezra Chitando, Troubled but not Destroyed: African Theology in Dialogue with HIV and AIDS (Switzerland: World Council of Churches Publications, 2009), 32-33.

21 It is important to point out that African Women's Theology embraces an interfaith approach and has established links with women from other faiths. See Melany Adonis, "An African Woman's Theological Analysis of a Development Programme: 'Churches, channels of hope'” (Masters Thesis, University of Stellenbosch, 2017), 73-74.

22 Isabel Phiri and Sarojini Nadar, eds., African Women, Religion and Health: Essays in Honor of Mercy Amba Oduyoye (Pietermaritzburg: Cluster Publications, 2011), 83.

23 Isabel Phiri and Sarojini Nadar, "The Personal is Political: Faith and Religion in a Public University" Acta Theologica: Supplementum 14, (2011): 83. 
economic injustice and oppressive religious and cultural practices. ${ }^{24}$ It confronts all factors that deny African women and others their basic human right to dignity. ${ }^{25}$

African Women's Theology is cognizant of the vital role women play in their communities, churches, and society at large and takes seriously women's experiences of dehumanization. Significantly, AWT is designed specifically for African women ${ }^{26}$ on the African continent. As such, it is deeply attuned to understanding and analysing the specific challenges African women in Africa face. AWT is also, unquestionably, ecologically attuned. Its gaze is not limited to analysis of women, but to all of humanity and nature.$^{27}$ It holds the view that women's struggle for liberation from all forms of oppression is a struggle for liberation for all of humanity and nature. As such, AWT is inherently ecologically sensitive. ${ }^{28}$ It is characterized by interrelationships, justice and transformation, and seeks to address challenges of contemporary life and struggles women in Africa are confronted with. ${ }^{29}$

African Women's Theology challenges the silence around issues of gender and the denial of women's agency and it maintains that women are not only survivors of oppression and domination but active agents in their own

24 Phiri and Nadar, "The Personal is Political," 83.

25 Adonis, "An African Woman's Theological Analysis," 73-74.

26 The term 'African women' is not used to categorize African women in Africa as a monolithic and homogenous group. I acknowledge that there are both similarities and differences between African women. In this article I wish to only convey that the term "African Women's Theology" clubs "African women" together under a common rubric that is based on shared challenges faced by African women in the context of Africa.

27 Martha Fredericks, "Miss Jairus speaks: Developments in African Feminist Theology" Exchange 32, no1 (2003): 72.

28 Philomena Mwaura, "The Circle of Concerned African Women Theologians and Their Engagement in Public Theology: A Pathway to Development," Online Journal (2015) http://journals.vonbi.ac.za. Accessed June 30, 2019.

29 Philomena Mwaura "The Circle of Concerned African Women Theologians and Their Engagement in Public Theology: A Pathway to Development," Online Journal (2015): 99, accessed June 30, 2019, http://journals.vonbi.ac.za. 
liberation. ${ }^{30}$ AWT's awareness of economic policies and systems and of how colonization, apartheid, globalization and issues of race, class and gender affect the lives of women in specific locales, puts it in a pivotal place to theorize the suffering, resilience, and agency of the group of women working on community urban food gardens in Pietermaritzburg.

\section{Resistance through solidarity: Navigating suffering and agency}

The starting point of AWT is women's experience. This analysis entails an enquiry into the nature of the oppression women face, the sources of oppression, and questioning what is being done to eradicate that oppression. Work is then undertaken towards empowerment and change. Schüssler-Fiorenza makes the point that women's suffering is located in the "structural interconnections between the gendered economic system of capitalistic patriarchy, its racist underpinnings, and women's global poverty." 31 The politics of economics, then, is one of the key reasons women suffer systemic injustice and oppression. In an attempt to understand such oppression and exploitation in any given locale, there is a need to capture the voices of women as they speak: of their experiences of being women, of the many forms their resistance to injustice takes, and of the vital elements such as spirituality and sisterhood that they embrace to make meaning of their lives and lift themselves out of dire situations.

As I journeyed with the group of women gardeners, I became deeply mindful of the embodiment of AWT in their lives - they embraced it, and through it, found ways to overcome the harsh conditions they faced. While the group of women were not aware of the theological, academic, and activist nature of

30 Nyambura Njoroge, "A New Way of Facilitating Leadership: Lessons from African Women Theologians," A Paper Presented at The American Society of Missiology (2004): 447, accessed on July 23, 2021,

https://repository.up.ac.za/bitstream/handle/2263/21579/018.

31 Elizabeth Schüssler-Fiorenza, "The Endless Day: Introduction," in Women, Work and Poverty, ed., Elizabeth Schüssler-Fiorenza and Anne Carr Concilium, (London: SCM Press, 1987): xviii-xxiii. 
AWT, they embodied its tenets in their day-to-day struggle for survival, their resistance to systemic injustice, and their agency in the face of overwhelming disparity. In an environment where under-resourced households struggled to put food on the table, these women used urban community food gardens as an important safe space to mobilize and draw on communal strength as they worked in solidarity to overcome poverty. Where conflict or disagreement arose within the group, the collective met regularly at PACSA with a mediator to iron out their differences. More importantly, the group of women maintained that prayer, fellowship, and building strong friendships with each other was an appropriate way to navigate differences and disagreements among them.

Resistance took on many forms among the women as they garnered social capital $^{32}$ through interaction with each other. Participation in urban community food gardens provided a space not only to grow their own food, thereby mitigating food insecurity, but also created a space where the women could unite in a common struggle. As I journeyed with them, we engaged in conversation about a wide range of issues, resulting in a depth of connection developing between us. I shared my own journey and struggles and listened to theirs. In the sharing of our life stories, our struggles and our victories, I realized how deeply beneficial such an exercise was, how our sharing helped each of us to develop our own self-confidence and selfworth. I recall the admiration I felt as I observed the camaraderie and genuine concern women showed for each other's well-being. Significantly, as is characteristic of women in South Africa, we sang as we worked, tilling the soil and invoking God's grace and aid in ensuring enough rain for the crops to grow and a bountiful harvest. Intermittently, we shared how our faith helped us through difficult times. In and through our interactions, I recognized the very tenets of AWT being lived out in everyday life by extraordinary women. As a group, united in a common struggle, the concern

32 Social capital exemplifies a network of relationships within a group or society which enables positive and productive interaction and, in turn, produces tangible or intangible results through networking, the exchange of ideas, and emotional and physical support. 
was first and foremost the empowerment of women and the recognition that every woman had something significant to offer on the road to transformation. In confronting the life-denying elements of poverty, and exclusion from mainstream economy, the group of women affirmed their interconnectedness with nature and recovered their human right to dignity. The power they exhibited was shared power, inclusive of all in the group and flowing freely from one to another. In and through all this, transformation was apparent.

\section{Oikos Theology}

Derived from the Greek language, the term 'oikos' means 'house' or 'household.' 'Oikos' therefore by implication refers to the earth, which is our home, and all of creation as belonging to the household. ${ }^{33}$ Oikos Theology encapsulates three essential components. Oikos-nomos, or God's economy, means 'the rules of the household.' Oikos-nomos speaks of God's engagement in creation. Economy and economic justice are always matters of faith and, as such, are at the very core of God's will for creation. ${ }^{34}$ Oikosnomos foregrounds the delicate balance of all life on Earth and is mindful of the balance that is essential between production, consumption and waste as humanity co-exists on the earth as God's household. Oikos-nomos insists that the current generation be cognizant of the generations to come in the ways in which the generations live on, live together and preserve the earth. Oikos-logos, or God's ecology, is intricately related to oikos-nomos. The economy of the earth cannot be separated from the earth's ecology. How we treat the earth's natural resources has a direct impact on the ability for life on Earth to either flourish or fizzle. In order to sustain life, both economy and ecology must be in perfect harmony. However, this harmony has been disturbed. Industrial and technological advancement broke the link between the two. Economy now implies the generation of wealth through aggressive exploitation of the earth's natural resources, treating the earth as a dump-

33 Diakonia Council of Churches, The Oikos Journey: A Theological Refection of the Economic Crisis in South Africa (Durban: Diakonia Council of Churches Publications, 2006), 23-24.

Diakonia Council of Churches, The Oikos Journey, 24. 
site and a receptacle for waste. Oikoumene, translated 'the whole inhabited Earth,' and the word 'ecumenical,' bring together the idea of the household of God along with some of the meanings of both economy and ecology ${ }^{35}$. Oikoumene speaks of God's engagement with the earth towards social justice, equality, reconciliation and a flourishing of the whole Earth and all of God's creation. ${ }^{36}$ As inhabitants of the household of God, humanity is called to be co-creators with God, seeking unity and mutual benefit of all the people of the earth. Oikoumene is governed by seven key principles ${ }^{37}$ :

1. The Earth, our home, is full of God's grace and love and our ability to survive depends on how we receive and appropriate God's grace and love. The exploitative nature of humanity's economics is incongruent to God's economics.

2. Labour can be both a blessing and a curse. On the one hand, humanity is called to be co-labourers and co-creators with God, making labour an expression of creative power. On the other hand, labour can be a curse when people do not have the right to the produce or products they produce. When their earnings are so meagre, they cannot afford to buy the very thing they have produced, hence, labour becomes oppressive.

3. There is a direct link between economy, ecology, human labour, human rest and human dignity. Rest, or the Sabbath, is God's way of reminding us that humanity has dignity beyond being units of production. God's rest calls us to acknowledge that economic systems must be subservient to the ethic of justice and equality. God's economy and God's ecology are designed to serve all. Where some prosper at the expense of others, it defeats God's intended purpose for economy and ecology coming together to form oikoumene.

35 Diakonia Council of Churches, The Oikos Journey, 25

36 Diakonia Council of Churches, The Oikos Journey, 25.

37 The principles are adapted from: Diakonia Council of Churches, The Oikos Journey, 2530 
4. God's prosperity is always shared prosperity. This shared prosperity is dependent on just, fair and appropriate management of God's ecology and equitable access to resources in God's economy. Economic justice is also ecological justice.

5. When prosperity is pursued at the expense of human dignity, it becomes life-denying, not life affirming, and is in direct contrast to God's plan and intention for the household of God.

6. God's economy is not only about structures and systems but a matter of discipleship - about how we as individuals live out our lives in the world; how we wrestle with and fight injustice, greed and oppression.

7. God's economy is not just about the present generation but about generations to come. As co-labourers and co-creators with God, humanity must live in a way that is sustainable so that the land, or the Earth, is preserved for generations to come. 38

\section{Resisting economic and ecological injustice}

Economic injustice breeds poverty and has a direct impact on the many vulnerabilities women face. In the quote below, a member of Diakonia Council of Churches spoke to a 34-year-old unemployed volunteer who worked on local community projects. The quote brings to light the reality of poverty and lack of food in under-resourced communities in South Africa:

I am a mother of five. There are no jobs and there is a high rate of illiteracy. Elderly people have no IDs to access pension. They have grandchildren to look after. The government is doing nothing about this. Some of these children have opted to sell their bodies in order to have something in their stomachs. I don't want to talk about this because it makes me feel so bad. ${ }^{39}$ 
The situation portrayed is indicative of the lived reality of many people in South Africa. Economic injustice puts women and children in harm's way because it is embedded in political and economic systems, thus disenfranchising the poorest of the poor. Moreover, economic freedom is often an elusive dream as economic opportunities are few in an environment where unemployment is rampant.

It is in this context that the group of women I engaged with became activists, environmentalists, community organizers, and urban food gardeners to address the economic challenges they face. The gardens, situated on the edges of the city on unused land, are tended regularly and with consummate dedication. The gardeners work on the premise that their foremothers tended and nurtured the soil until it yielded nourishment and that gardening is, therefore, an established and viable measure to counteract food insecurity. The women spoke of how urban existence and segregated living under apartheid robbed them of the vocation of farming the land and providing sustenance for their families. In tilling the soil, planting and harvesting, they rely on indigenous knowledge handed down to them by their mothers and grandmothers. They know instinctively when to plant and when to harvest, when to water the soil and when to leave it up to the weather, which crops to plant in particular seasons, and the importance of crop rotation.

By reclaiming access to the land, the community urban food gardeners live out the first principle of Oikos Theology - the Earth is full of grace and love. Food gardening is both an expression of creative power and a means of nourishing provision. It is through community food gardening that the work of their hands becomes a means of overcoming oppression. It is resistance to structural socio-economic subjugation and injustice. Through such resistance, the women are able to enjoy the fruits of their labour. In this nexus, they live out the second principle of Oikos Theology - their labour is a blessing to themselves and their families. In their labour, time is allocated for rest and restoration, a sublime reminder that they are not part of the status-quo; that they have dignity beyond being mere units of production. In this mutually beneficial relationship between themselves and the earth, they 
uphold an ethic of ecological justice and equity that serves all. In this way, they live out the third principle of Oikos Theology - Sabbath or rest is the fundamental rule of God's economy. Eco-justice is part and parcel of God's economy. This sentiment is echoed by Pope John Paul II in Peace with God the Creator - Peace with all Creation: ${ }^{40}$

It is manifestly unjust that a privileged few should continue to accumulate excess goods, squandering available resources, while masses of people are living in conditions of misery at the very lowest level of subsistence. Today, the dramatic threat of ecological breakdown is teaching us the extent to which greed and selfishness-both individual and collective are contrary to the order of creation.

In God's economy, humanity is called to be the protector of the environment and all living things. This point was clearly illustrated at the food garden on one particular occasion. As a group, we made a line across the field and began to till the soil. The person directly next to me uncovered a nest of snake eggs in the soil. Petrified, I threw down my shovel and ran to safety. This action was met with hilarious mirth by my fellow gardeners. From a distance I yelled, "Why aren't you afraid?" My companions, gesturing for me to return to the line, explained that all living things must live and thrive on the land; the land is not just for humans. Each creature has a role to play in God's delicate eco-system. "Besides", they quibbled, "humans are more of a threat to snakes than snakes are to humans." "They will not harm you," I was told. "In fact, they move away from the threat of human presence."

The women gardeners also spoke of how the harvest was shared equally among them. Some of the harvest was for household use and some was sold at market places to supplement their incomes. In a world where progress is often characterized by greed and personal gain alone, this system was to me a refreshing change. In this, I recognized the fourth

40 Stephen Scharper and Hilary Cunningham, The Green Bible, (Maryknoll: Orbis Books, 1993), 71-72. 
principle in Oikos Theology - shared prosperity is the goal of God's economy.

The fifth principle of Oikos Theology - we cannot serve God and selfish greed, is a stark reminder that in our world of greed and the scramble for self-enrichment, the value of money often takes precedence over the value of people and the value of the environment. With the rapid degradation of the earth's natural resources and the widespread exploitation of the poor, it is a reminder that prosperity has its limits. Detached from justice and equity, prosperity becomes an all-consuming object of worship. ${ }^{41}$ The food gardeners displayed a deep respect for the environment and the understanding that humanity needs to work with nature, not exploit it, so that everyone can reap the benefits of their labour and the earth is preserved.

The sixth principle of Oikos Theology - God's economy is a matter of discipleship--is an indication of our role as stewards of the earth and of each other. As humanity, we have a corporate responsibility to be stewards of creation and of all the earth's resources. This lesson was demonstrated clearly by the food gardeners who chose to work in unison with nature and with each other.

The seventh and final principle of Oikos Theology - we are called to live long in the land-is an appeal to humanity to preserve natural resources, limit pollution, and promote eco-justice - so that generations that follow us may enjoy the earth's abundance. A poignant display of the food gardeners' deep respect and passion for preservation of the earth occurred during one of my conversations with a particular young woman. She explained to me that what we put into the soil has a lasting effect and that if what is put in the soil results in degradation, it will have an effect on the crops produced for hundreds of years to come. She also shared the following words of wisdom pertaining to responsible stewardship of the earth:

41 Diakonia Council of Churches, The Oikos Journey, 29. 
Never use harmful chemicals, instead, in order to get rid of bugs that eat the plants, we use a mixture of vinegar and water. We never allow anyone to throw plastic or other materials on the ground. If we see them lying around, we pick them up and give it to people who recycle. We collect fruit and vegetable peels and natural stuff to make manure. We also teach children and people in the community how to treat the soil, not to throw harmful things such as oil in it because that will destroy the soil. This is how we preserve the land for the future.

The lens of Oikos Theology makes clear that the oppression of women and the degradation of nature is interlinked. Through a deep connection with nature, ecology and indigenous knowledge systems, these women gardeners demonstrate how self-determination, self-reliance and agency in the face of overwhelming odds can contribute to community development and environmental sustainability.

\section{Conclusion}

In sum, I discussed how, through urban community food gardens, a group of women from under-resourced communities in Pietermaritzburg, KwaZuluNatal, resist food insecurity perpetuated through structural and systemic oppression. I argued that they demonstrate agential action through solidarity with each other, cooperation with nature, and the use of ecological and indigenous knowledge in their gardening initiative. Through the lens of AWT, I addressed issues of suffering, solidarity and agency, and through the lens of Oikos Theology I demonstrated how ecological and indigenous knowledge applied in the tending of urban community food gardens resulted in a mutually sustaining relationship between the food gardeners and the earth. This collaboration not only served to mitigate food insecurity but also led to the urban community food gardeners becoming agents of transformation and change within their own communities. 


\section{References}

Adonis, Melany. "An African Woman's Theological Analysis of a Development Programme: 'Churches, Channels of Hope." Masters Thesis, University of Stellenbosch, 2017.

Battersby, Jane. "A Call for a Food Systems Approach to Alleviating Food Insecurity," Input for Province, (September 2015): 1-10.

Chikane, Frank. "Reflections of South Africa's Oikos Journey: From Apartheid to Democracy by the Reverend Frank Chikane on the Occasion of a Discussion on the Oikos Journey Document," Diakonia, October 18, 2006.

Diakonia Council of Churches. The Oikos Journey: A Theological Refection of the Economic Crisis in South Africa. Durban: Diakonia Council of Churches Publications, 2006.

Dodson, Belinda., Asiyati Chiweza and Liam Riley. "Gender and Food Insecurity in Southern African Cities." AFSUN Food Security Series, no. 10 (2012): 3-29.

Fredericks, Martha. "Miss Jairus Speaks: Developments in African Feminist Theology," Exchange 32, no. 1 (2003): 76.

Madlala, Petros. "The Role of Food Gardens in Providing Sustainable Livelihoods in the Msunduzi Municipality." Masters Thesis., University of KwaZulu-Natal, 2012.

Manda, Charles. "Doing Theology at the Margins: PACSA's Accompaniment of Communities in the KwaZulu-Natal Midlands, 1979-2012." Studia Historiae Ecclesiasticae 40 no. 2 (2014): 263-280.

Mwaura, Philomena. "The Circle of Concerned African Women Theologians and their Engagement in Public Theology, A Pathway to Development." Journal of African Women's Studies (2015). Accessed June 30, 2019. http://journals.vonbi.ac.za . 
Njoroge, N. "A New Way of Facilitating Leadership: Lessons from African Women Theologians," A Paper Presented at The American Society of Missiology (2004): 447, accessed on July 23, 2021, https://repository.up.ac.za/bitstream/handle/2263/21579/018 .

Phiri, Isabel and Nadar, Sarojini, eds. African Women, Religion and Health. Essays in Honour of Mercy Amba Ewudziwa Oduyoye. Pietermaritzburg: Cluster Publications, 2006.

Phiri, Isabel, and Nadar, Sarojini. "African Women Theologies." In African Theology on the Way: Current Conversations, edited by D. Stinton, London, UK: SPCK, 2010.

Phiri, Isabel, and Nadar, Sarojini. "The Personal is Political": Faith and Religion in a Public University." Acta Theologica: Supplementum no. 14 (2011): 181-94.

Sachikonye, Tawanda. "African Feminism Driven by African Women," 2010. Accessed on June 30, 2019. http://www.consultancyafrica.com .

Scharper, Stephen and Cunningham, Hilary. The Green Bible. Maryknoll: Orbis Books, 1993,71-72.

Schüssler-Fiorenza, Elizabeth. "The Endless day: Introduction.” In Women, Work and Poverty, edited by Schüssler-Fiorenza, Elizabeth and Carr Anne, Concilium 164. London: SCM Press,1987, xviii-xxiii. 